\title{
THE ORIGINS OF THE ACTION OF TRESPASS ON THE CASE
}

\author{
ELIZABETH JEAN DIX $†$
}

Withis the last decade the origins of the action of trespass on the case have become a controversial subject arousing interest anong lawyers and historians as well as anong those more specialized hybrids, legal historians. It the beginning of this century no one questioned the theory of the origins of the action proposed by Anes, Holmes, Holdsworth, Salmond and others. ${ }^{1}$ It was generally believed by these writers that the action of trespass on the case was a direct derivative from the well known in consimili casu clause of Edward I's Statute of 1285, Westminster II, chapter 24. Belind this belief was the support of older writers. Chitty, Reeves, Stephen and Blackstone," confirming beyond doubt the relationship between the action of case and Westminster II. In the course of the last thirty years, however, attention has been directed to flaws in the generally accepted theory of the origin of case. The objections were strongly voiced several years ago by Mr. Theodore $F$. T. Plucknett, who concluded fron his study that the background, content and results of the Statute of Westminster II, and particularly of the in consimili casu clause, indicated that the action of case had no connection with the Statute. ${ }^{3}$

There are two sides to the present controversy: one is represented by Mr. Plucknett himself; the other is represented by Sir William Holdsworth ${ }^{4}$ and his associate at Oxford, Mr. P. A. Landon." In support

$\dagger$ Pl.D., Yale University, 1936. This article is part of a dissertation presented for the degree of Doctor of Philosophy in Yale University, June, 1936.

1. The opinion of Holmes was that "the famous statute of 13 EDwand I, c. 24, authorized the office from which the old writs issued to frame new ones in cases similar in principle to those for which writs were found, and requiring like remedy, but not exactly falling within the scope of the writs already in use. Thus writs of trespass on the case began to make their appearance; that is, writs stating a ground of complaint analogous to a trespass, but not quite amounting to a trespass as it had been sued for in the older precedents." Holmes, The Coxmon Law (1881) 274-75. See Ames, Lectures on Legal History (1913) 442; 2 Holdsworth, History of English LaW (1923) 365; Maitland, Equity and the Fordss of Action (1909) 345-46; Saldiond, Law of Torts (8th ed. 1934) 4, n. q.; 3 Street, Foundations of Legal Liability (1906) 249; Sutton, Personal Actions at Common Law (1929) 24 et seq.

2. 3 Bl. Comm. *122; 4 id. at *442; 1 Chitty, Pleading *95-96; 3 Reeves, History of the English Law (1787) 89; Stephen, Pleading *15-16.

3. Plucknett, Case and the Statute of Westminster II (1931) 31 CoL. L. Rev. 778; see also Plucknett, Case and Westminster II (1936) 52 L. Q. REv. 220.

4. Note (1931) 47 L. Q. REv. 334.

5. Landon, The Action on the Case and the Statute of Westminster II (1936) 52 L. Q. REv. 68. 
of their Traditionalist ${ }^{6}$ position, the latter two have analyzed the generally accepted theory and have reduced it to an apparently logical and watertight conception of the developnent of the action on the case: ${ }^{\top}$ (1) The name of the action on the case is a derivative of the phrase "on the case" used to describe a writ suited to the plaintiff"s "case."

(2) These writs "on the case," described by Bracton as breria magistralia, existed in the common law at least as early as the thirteenth century. (3) The power to issue these writs, temporarily curtailed by the Provisions of Oxford in 1259," was restored and strengthened by the in consimili casu clause of the Statute of Westminster II. (4) Consequently, after 1285 the Chancery developed new writs "on the case," chief among which was the writ of trespass on the case. (5) Therefore, though writs "on the case" antedated the Statute of Westminster II, it is correct to say that the writ of "trespass on the case" was a direct product of the in consimili casu clause of that Statute.

The annunciation of the Traditionalist theory was provolied by Mr. Plucknett's study of Westminster II and its relation to case. Mr. Pluclnett had stated ${ }^{10}$ (1) that the Statute in part and as a whole can be properly

6. The title is Landon's own. Landon distinguishes between three historical schools: Plucknett's group; a Mrodern group, represented by Ames, Holmes, Sutton and others, which has engrafted upon a basically sound idea some fallacious assumptions; and his own Traditionalist group. The Traditionalists recognize the errors of the Modern group, but hold to the same general conception of the origin of ease. As Landon puts it, the Traditionalist theory of Blackstone, Reeves, and Steplien has been sanctified by the leading lawyers for so many centuries that criticism of it is ridiculous.

7. Landon, loc. cit. supra note 5.

8. It is on this first point, according to Landon, that the Modern group and the Traditionalists split. The Modern group says that the name of the action of trespass on the case came from the phrase "in consimili cast" in the Statute of Westminster II, c. 24. Trespass on the case is "so called because the writ was issucd in consinili cass cadente... (in analogous circumstances and falling under the same law and requiring the same remedy) as trespass." SALsosn, loc. cit. supra note 1 ; cf. Surro:, loc. cit. supra note 1 . With good reason Landon and the Traditionalists believe that the name of the action on the case came from the form of the writ and had nothing to do with the in consinili casu of the Statute. By overlooking this difference between the Mrodern group and the Traditionalists. Plucknett has confused the real issue of the origin of the action as a whole. Up to the middle of the nineteenth century all writers believed that the name of the action signified that it was begun by a spccies of writ which included all the matter of the case. See, e.q. Conel. Iviterpretre (1637) f. B 1 b; Jacoe, Law Dictronary (2d ed. 1809) f. D; R.sstell, Termes ne li Lex (1742) 17. Blackstone's definition, borrowed from Lambard, is that a writ of case gives the suitor "ready relief, according to the exigency of his husiness, and adaptcd to the specialty, reason and equity of his very case;" for a wrong or injury unaceompanied by force "there is a remedy in damages by a special action of trispass upon the case . . . so called because the plaintiff's whole case or cause of complaint is set forth at length in the original writ." 3 BL. Comm. ${ }^{*} 122$.

9. 1259. 23 HEN. III.

10. Plucknett, loc. cit. supra note 3, 31 CoL. L. REv. 
understood only when considered in its historical setting; (2) that this consideration leads to the belief that the in consimili casu clause was intended not to increase the writ-issuing power of the Cliancery, but to provide machinery for the reference to Parliament of disputed petilions for writs, as a last recourse beyond the Chancery itself; (3) that the writs resulting from the in consimili casil clause are few and definite, the writ of entry in consimili casu, the writ of ravishment of ward for socage tenure, and possibly a few others mentioned in the Register of Writs; (4) that each writ unquestionably derived from chapter 24 concerns real property, while case applied to real property only late in its development; (5) that the Year Books mention no connection between the Statute and case; and (6) that the first suggestion of a connection between the two was made by William Lambard in the Archcion, ${ }^{11}$ whence Blackstone borrowed the idea and popularized it. Plucknett's conclusion is that historically the action on the case could not have come from the Statute of Westninster II, that no one believed in the origin of the action in the Statute until at least the beginning of the seventeenth century, and that the theory was not generally credited until the end of the eighteenth century, when Blackstone's sponsorship provided the prestige on which the belief has lived ever since. ${ }^{12}$

P'lucknett's attack on the generally accepted theory of the origin of case is entirely destructive; his sole ain is to show that the action probably did not come from the statute. ${ }^{13}$ The Traditionalists, on the other hand, emphasize their conception of the way in which case originated - a positive theory of the course of events - with such vigor that they overlook or minimize the contradictory information brought out by Plucknett. There are certain difficulties that preclude unqualified acceptance of the Plucknett view, ${ }^{14}$ especially because it offers no substitute for the Traditionalist theory; and conversely, the Traditionalist theory

11. Lambard wrote the ARCheion about 1591, but it was not published until 1635 . For the statement on case and the Statute of Westminster II see Lambard, ARCHEroN (1635) 61-62.

12. Plucknett could have made his point even more strongly by indicating that it was Blackstone who first mentioned the in consimili casu clause in connection with the action on the case. 3 BL. Comm. *52. Lambard quoted a few lines of the Statute, from the first and possibly the twenty-fourth chapters [Lambard, ARCHeion (1635) 61], but he did not cite the in consimili casu clause. It was Blackstone who first introduced that bit of the Traditionalist theory some five hundred years after the appearance of the action.

13. Remarks suggestive of the origins of the action on the case are found in his Concise History of the Common Law (2d ed. 1936) 335, 414-16.

14. Plucknett's treatment of the meaning and significance of the Provisions of Oxford [1259, 43 HeN. III ; Stubbs, Select Charters (9th ed. 1913) 378] is not universally acceptable; and his assumption that all modern writers believe that the name of the action on the case came from the in consimili casu clause is probably an overstatement. 
is weakened considerably by its failure to account for some of the facts stressed by Plucknett. ${ }^{15}$

The situation at the present time is, therefore, that each of the parties to this controversy stoutly maintains his own position, the question is not settled, and most of those who might be interested in a resolution of the dispute continue to think and teach that case came from the in consinili casu clause. The purpose of the present paper is constructive rather than controversial. The subject is so obscure that it may never be possible to establish the origins of the action of trespass on the case by an offer of historically incontrovertible evidence. But the evidence that now exists indicates first that the action of case did not come from the Statute of Westminster II, and second that the action was a gradual and evolutionary common law development, in the late fourteenth and the fifteenth centuries, out of the older action of trespass ai at armis.

\section{Action on the Case and the Statute of I'estarinster II}

That the action of trespass on the case did not develop from the Statute of Westminster II is indicated by a study of the Statute in the light of the condition of the judiciary in the thirteenth century. ${ }^{10}$ It has been commonly supposed that the Statute set up a machinery for the issue of new writs by the Chancery, and that the best known product of that machinery was the writ of trespass on the case. If it is true that the Statute did establish machinery by which the writ of trespass on the case was formulated, then it would not be too much to say that the action came from the Statute, even though it appeared long after the Statute had been enacted. The connection between the action and the Statute is much less clear, however, if the machinery set up by the Statute was not for the issuance of new writs, or if there is no indi-

15. Landon has yet to prove that the popularization of the Traditionalist theory of the origin of case was not the work of Blackstone, who took it irom Lambard. And the Traditionalist view that the action on the case existed in the thirteenth century, before 1285 , lacks conviction because of their apparent ignorance of recent worl: on the development of the action of trespass in the thirteenth century. See Woodbine, The Origins of the Action of Trespass (1924) 33 Yale L. J. 799, (1925) 34 Yale L. J. 343.

16. Plucknett has made a rather exhaustive study of the Statute itself in its historical background [Plucknett, loc. cit. suira note 3, 31 CoL. L. REv.], luut it scems advisable to reconsider the matter. Landon's article [Landon, loc. cit. suspra note 5]. which has appeared since Plucknett's, has raised some new questions (notably that of the brevia magistralia) which Plucknett did not discuss. And I do not entirely agres with some of Plucknett's conclusions concerning the thirteenth century lialisaround. especially concerning the effect of the Provisions of Oxford [Pluclnett, sngra nute 3. 31 CoL. L. Rer. at 793-94]. But Plucknett's statement that "the action of ease is unrelated to the statute," is still acceptable. Plucknett, supra note 3. 31 Cur. L. RE. at 783. 
cation that the writ of case was in fact developed in accordance with that machinery. The problem is reduced, therefore, to deciding whether the statute created a chancery procedure for issuing new writs or for issuing writs like Bracton's brevia magistralia of the early thirteenth century, ${ }^{17}$ and to deciding whether there is any evidence that the writ of case was the result of the chancery procedure established.

A determination of the effect of chapter 24 of the Statute of 1285 on the issuing of writs by the Chancery depends in part upon the stated purpose of the chapter: "In cases in which a writ is granted in the Chancery because of the act of someone, from henceforth the plaintiffs shall not leave the King's court without a remedy because the tenement has been transferred from one to another. . . ."18 The clapter proceeds to give three examples of the extended remedies: the assize of nuisance, which thereafter could be brought against the alienee as well as against the levyor and alienor of a tenement upon which a nuisance had been levied $;^{19}$ the quod permittat, which thereafter could be used by a parson against the disseisor or his heir to recover common of pasture lost by his predecessor, just as before the Statute the parson's predecessor could have recovered by a writ of novel disseisin, ${ }^{20}$ and the assize utrum, which was extended to try the question of right between two churches where the tenement in dispute had been alienated from one church to another. ${ }^{21}$ Apparently chapter 24 gave three specific examples of forms of writs which henceforth were to be issued by the Chancery under circumstances slightly variant from those in which they had previously been issued. This was in accordance with the principle stated in

17. See Landon, sipra note 5 , at 74-75.

18. "In casibus quibus conceditur bre'c in Canccllaria de facto alicuius decetero non recedant quercntes a curia Regis sine remedio, pro eo quod tcnementum transfertur de uno in alium . . ." Statute of Westminster II, 1285, 13 EDw. I. c. 24; see text in 1 Statutes of the Realar (1810) 83 and in Plucknett, stpra note 3, 31 Col. L. Rev. at 789. The Statute continues: " . . . et in registro de Cancellaria non est inventum aliquod brea'e in illo casu speciale, etc."

19. Statute of IVestminster II, c. 24; see Registrum Brevium (1687) f. 198, where there is a regula stating that the writ came from the Statute.

20. Ibid.; see Registrum Brevium (1687) f. $155 \mathrm{~b}$.

21. Ibid. Before the Statute the assize lay to inquire whether a tenement was a lay fee or the free alms of a church. Ibid.; see Registrum Brevium (1687) f. $32 \mathrm{~b}$. On the character and development of this curious remedy which began as an assize to determine jurisdiction and ended as the parson's writ of right see Kimball, The Judicial Aspects of Frank Almoign Tenure (1932) 47 ENG. Hist. Rev. 1; Kimball, Tenure in Frank Almoign and Secular Scrices (1928) 43 Exg. Hist. Rev. 341; Thorne, The Assize Utrum and Canon Laze in England (1933) 33 CoL. L. Rev. 428. According to Pollock and Maitland, the Statute of Westminster II removed the last traces of the early nature of the action. 1 Pollock and Maitland, History of English Law (1905) 250; see also Glanvill, De Legibus et Consuetudinibus Regni Angliae (Woodbine ed. 1932) 286 (note on c. 23). 
the chapter that he who would hitherto have been deprived of a remedy because of the transference of the tenement should henceforth have a remedy despite that alienation. None of the remedies given was new; each was a well known form of writ, with a clange only in the parties to the suit.

A similar but more general provision for the extension of familiar remedies to slightly varying cases is found in the last paragraph of the twenty-fourth chapter, containing the in consimili casu clause:

"And whenever henceforth, it shall happen in the Clancery that in one case a writ is found and in a like case falling under the same law and requiring a like remedy [no writ is found], then the clerlss of the Chancery shall agree in making the writ, or they may adjourn the plaintiffs until the next parliament, and let them write the cases in which they cannot agree and refer them to the next parliament, and let the writ be made with the consent of the wise men of the law; and from henceforth, let it not happen that the court any longer fail complainants seeking justice." 22

The actual meaning of this paragraph can be determined only by a consideration of the rest of the Statute. The purpose of the Statute of Westminster II was to fill the gaps in the common law ${ }^{23}$ by creating legal remedies for certain cases then unprovided for by common or statute law. This purpose was carried out by three types of provisions: first, by the provisions for the better enforcement of previously created statutory remedies, such as the writ of cessacit given by the Statute of Gloucester ; ${ }^{24}$ second, by the provision for entirely new remedies, such as the famous writ of formedon, ${ }^{25}$ and third, by the provision for the formulation of similar writs for similar cases both at that time and in the future. This third objective was achieved in the twenty-fourth chapter, through the forms of writs there rehearsed and through the definition in the last paragraph of the way in which these similar forms of writs could be obtained.

22. "Et quocienscanque, decetero cvencrit in Cancellaria qued in uno cass rescritur breve, et in consimili casu cadente sub eodens jure et simili indigente remedio, concordent clerici de Cancellaria in brezi faciendo, acl atterminent querentes in proximo parleamento, et scribant casus in quibus concordare non posstut, ct referont cos ad jrezimusm parleamentum, et de conserssu jurisparitorum fiat breve; ne contingat decetero quod curia dis deficiat querentibus in justicia perquircuda." Statute of Westminster II, c. 24.

23. Id. at Preamble and c. 50; 1 Statutes of trie Reni:s (1810) 71, 95; see Asres, loc. cit. supra note 1. Twenty-eight chapters of the Statute are concerned with real property actions; the others deal with crimes, debt, process, accuunt, cummissioning of justices, delivery and return of writs by sheriffs, and so forth.

24. Id. at c. 21; Statute of Gloucester, 1278, 6 Enw. I, c 4; 1 Starutes of IaE Realax (1810) 48. See Plucknett, supra note 3,31 CoL L Rev. at 790.

25. Statute of Westminster II, c. 1. 
This attempt in 1285 to supply the deficiencies in the common law would hardly have been necessary fifty years earlier. During the first half of the thirteenth century the common law of England was expanding rapidly in all directions, ${ }^{20}$ not through statutory enactment, but through the cooperation of the King's courts and the Chancery in trying to grant a remedy for alnost every wrong presented for their consideration. ${ }^{27}$ There were, perhaps, some political reasons for this expansion of the law. The King's courts were trying to draw to themselves the major portion of the judicial business of the realm in order to supplant the local and feudal courts. ${ }^{28}$ To effect this end they were willing to give a remedy to almost any complainant who appeared before them. ${ }^{20}$ The Chancery, also eager to enhance the power of the King and the central government which it represented, aided and abetted the courts by establishing writs that enabled complainants to get their cases into the courts. ${ }^{30}$

A second reason for the flexibility of the forms of action in the early thirteenth century lies in the principle of damages, so important in English law. which had just been introduced through the medium of the assize of noz'cl disscisin and was gradually spreading to the other forms of action. ${ }^{31}$ Until after 1250 these actions for damages took no one fixed form, but were brought usually by a complaint in the form of a quare writ out of the Chancery. ${ }^{32}$ The range and variation as well

26. This growth becomes evident in comparing the highly developed law of BracTON'S DE LEGIBl's with the writs in Glanvill's work and in the early IRISH REGISTER of WRITs; the latter are primarily basic writs, c.g., the writ of right, the assizes of novel disscisin and mort d'ancestor, the action of debt, and certain criminal actions. See Maitland, The History of the Register of Original Writs (1889) 3 HARv. L. REv. 97, 108 st seq.; 2 Maitland, Collected Papers (1911) 110, 126 et seq.

27. 1 Bracton's Niote Book (Maitland ed. 1887) 1-7. The Provisions of Merton, 1236, $20 \mathrm{HEN}$. III, represent the only early statute of any importance.

28. 1 Pollock and Maitland. History of Englisi Law (1905) 195-97.

29. 1 Bracton's Note Book (Maitland ed. 1887) 1-7.

30. For a description of the freedom of the Chancery in issuing writs before 1259 see Bracton, De Legibús f. 414b.

31. Woodbine, supra note 15, 33 Y ALE L. J. at 802.

32. It is possible that these formless quare actions were synonymous with the midthirteenth century brcaia magistralia which Landon claims were "actions on the case." Landon, supra note 5, at 74. Everything that is known of the brearia magistralia is in a section from Bracton's treatise describing the issue of writs by the Chancery. Bracton, De Legtre:s f. 413 b; see Doderidie, The English Lawyer (1631) 45; 2 Holdsworti, History of English Law (1923) 245: 1 Pollock and Maitland, History of EngLish Law (1905) 194, n. 1; Landon, supra note 5, at 73; Plucknett, supra note 3, at 793. The brevia magistralia here presented were contrasted with the brevia formata because the form of the latter was fixed by usage and could be varied only by the consent of the "common council of the whole realm." These brevia formata, we know, were writs of right, dower, and debt, and assizes of novel disseisin-old and established writs of course. On the other hand, the brcia magistralia, like the quare actions, were flexible, 
as the frequency of these quare actions, can be seen in the cases in Bracton's Note Book. ${ }^{33}$ In classifying the forms of action appearing in the Note Book, Miaitland devoted an entire section to "miscellaneous proceedings," the majority of which were quare actions of some hind; and another section to trespass cases, most of which really were not fully developed as trespass but were quare actions evolving towards trespass.

By the latter part of the thirteenth century, the nature of the common law had been changed by the emergence of the formalized action of trespass from these hybrid quare actions and by the establishment of the King's courts as the controlling judiciary of the kingdom. Secure in their position, the central courts turned their attention to systematizing and formalizing the law they applied. ${ }^{34}$ The Chancery, pervaded by the same spirit and repressed by the Provisions of Oxford ${ }^{35}-a$ result

designed to suit the situation at hand; and during the time of Bracton, before 1259, these variant writs could be issued without the specific assent of the "common council." Bracton, De Legirus f. $414 \mathrm{~b}$.

33. I Bracton's Note Book (Maitland ed. 1887) 184-126 (Group VIII). Of course, not all of these are quare actions. See id. at 1S6, under Trespass. There are other quarc actions in 1 Select Civil Pleas (Selden Society 1890). Landon is justified in saying that in their formlessness and adaptability actions in the nature of the quare aetions or of actions begun by Bracton's brezia magistralia were similar to the later actions on the case. But by his failure to take into account Woodbine's sesearch into the origins of the action of trespass [Woodbine, loc. cit. supra note 15], he misses Woodbine's point that some of the quare actions, and presumably the brevia manistralia, represented actions in the transitional stage, after the middle of the thirteenth century, before the emergence of the action of trespass. Landon, following Amss and Rigg, appears to believe that trespass was a well established action tefore the time of Bracton, and therefore is unable to understand the quare actions and other formless actions as forerunners of trespass itself, not of trespass on the case. Landon, sufra note 5 , at 75, n. 35; see Rigg's edition of the Select Pleas of the Excrequer of the Jews (Selden Society 1902) ; Anes, Lectures on Legal History (1913) 44; 2 Holrswomta, History of ENGLISH LAW (1923) 364.

34. The conservatism of the judiciary did not stop at denying an action to private litigants; on at least two occasions the courts threw out writs of gtto asrrombo hrougint by Edward I. Placita de Quo Warranto Terrfodues (1818) 6\$1, 696; see 1 Rortu Parliassentordar (1767) 52, where Edward I complained of having no writ. The result was the Statute of Gloucester, 1278, 6 Evw. I. The same spirit is demonstrated in the early Year Books: every new or unusual form of writ had to ha elabonately ilafended and justified by the plaintiff, frequently without avail. E.t.., Adam v. Waltham. Y. B. 21 \& 22 Edw. I, [R.S.] 320 (1294); Abbot of C. v. Earl of Warren, Y. B. 21 \& 22 Edw. I, [R.S.] 526 (1294); Tauney v. St. Omers, Y. B. Trill. 32 \& 33 Elw. I, [R.S.] 282 (1304); St. Michael v. Beauchamp, Y. B. Hil. 33 \& 35 Edw. I, [R.S.] 426 (1307).

35. 1259, $43 \mathrm{HEN}$. III. The bearing of the Provisions of Oxford upon this controversy has been much disputed. But it seems that the provisions concerning the chancellor restricted his power considerably, particularly in the issue of evtraordinary writs such as the brevia magistralia or quare writs. Provisions of Osford 14 A:itinles Bu:tonenses (1684) 446-453; Stubrs, Select Charters (9th ed. 1913) :28; 386]. As we 
of the temporarily successful opposition of the Barons to the growing centralized power of the King - ceased granting writs not already established in their registers in a set form. Out of the quare actions, as formless actions for damages in general, emerged the specialized writ of trespass; but the writ of trespass granted redress for injury done by direct force, and did not apply to other types of injuries. Thus a spirit of conservatism settled upon the courts and upon the Chancery, producing an ossification of the system of writs, which was to change little except by statute for several hundred years.

That this ossification had set in by the year 1285 is indicated by the quocicnscunque clause in which Edward turges the use of new and variant remedies. ${ }^{36}$ The Statute of Westminster II would have been an anomaly in the "golden age of the forms of action," as Pollock and Maitland had called the earlier thirteenth century. ${ }^{37}$ But by 1285 this Statute was needed to counteract the formalism and conservatism of the Chancery and of the courts. The provisions of chapter 24 and of the rest of the Statute were attempts by Edward to provide remedies for otherwise remediless plaintiffs. And the in consimili casu clause was intended to authorize a petition to Parliament for variant forms of writs should the chancery clerks and the "wise men" of the realm fail to grant the necessary writs. ${ }^{38}$ These writs, however, were to be secured only for a "like case falling uncler the same law and requiring a like remedy" to a writ already in existence. ${ }^{39}$ It would be safe to assume, did the lear Books not prove the point conclusively, that the reactionaries in the Chancery and in the courts would place a very strict interpretation upon the degree of "similarity" required in such situations.

It seems, therefore, that the Traditionalist position that the chapter restored to the Chancery the power to issue brevia magistralia denied to it by the Provisions of Oxford ${ }^{40}$ is quite untenable in the light of the

know from Bracton, prior to 1259 the consent of the magnates was not necessary for the issue of an unusual writ if they did not expressly dissent. Bracton, De Lecrnus f. $414 \mathrm{~b}$. But after the Provisions of Oxford the King's authorization was not enough to justify the Chancellor in establishing a new form of writ.

36. See note 22, supra.

37. 2 Pollock and Maitlañ. Histori of English Law (1905) 564.

38. Many early fourteenth century petitions to Parliament are preserved in the printed Rolls of Parliament; some are clearly of the type suggested by the Statutepetitions seeking a method for the judicial redress of grievances, e.g., the petition made by Agnes Frowyk. Other petitions were less judicial or more extraordinary in nature. Frowyk v. Leukenore, 1 Rotul Parfiamextorum [1767] 278, no. 27 (1308-1309). See notes 50,120 , infra.

39. Several passages in Bracton show that the phrase "in consimili casu" was used in the thirteenth century in a purely descriptive manner to mean "in a like situation," with no suggestion of the technical meaning that might be connected with the "case" of action "on the case." Bracton, De Legrbus f. 370, f. 398.

40. Landon, supra note 5 , at 75 . 
Statute's background. The brevia magistralia were a phenomenon of the "golden age of the forms of action," and by 1285 that age had passed away forever. Edward I probably could not have revived it if he had wished. And the Statute of 1285 bears no mark of such a desire on Edward's part. It did not provide for the issuance of formless writs like the old quare actions and like the later writs of case; it merely provided, as far as we are interested here, for the issuance of variant forms of regularly established writs, and, where the Chancery would not accommodate the petitioner, for the reference of the petition to Parliament. In the Chancery and, beyond it, in Parliament there still rested the discretion to decide what variant forms of writs were to be granted: these bodies had the power to interpret the provisions of the Statute; and the courts retained the prerogative of refusing to uphold the forms of variant writs granted by the Cliancery or by Parliament.

The Traditionalist position is further weakened by the strict construction applied by the Chancery and the courts to the in consimili casu clause in the Statute of Westminster II. As far as is known, only two writs ${ }^{41}$ were actually framed under the provisions of the in consimili casu clause, the writ of entry in consimili casut ${ }^{42}$ and the writ of ravishment of ward for socage tenure. ${ }^{43}$ The former writ, an extension of the writ of entry in casu proziso given by the Statute of Gloucester," was

41. The Year Book cases [see note 34, supra] concern variant forms of writs justified by the plaintiffs in each instance as derived from the Statute of Westminster II, though not necessarily from c. 24. But none of these writs scem to iave been then established. The Register also contains several writs connected with the Statute by marginalia. For example: "Regula: Istud breie non datur per statutum, sed potest salieari per statutum $W$. secundi, cap. 2.4 in consimili cast ctc." Regrstrusa Brevius (1687) f. $199 \mathrm{~b}$ (writ of quod permittat). This statement does not necessarily imply that the writ was framed with the Statute in mind. Parties often referred to statutes in order to confuse their opponents.

42. Registrum Breviun (1687) f. 236, 236b.

43. Registrum Brevium (1687) f. $161 \mathrm{~b}, 162$.

44. 1278, 6 Evw. I, c. 7. Prior to the Statute of Gloucester there had existed a writ of entry ad communem legcm, which allowed the reversioner to recover after the death of a tenant for life, in dower, or by the curtesy, when the tenant had conveyed. The limitation of actions during the tenant's lifetime was something of a lazrdship, however, because if the tenant for life died long after the alienation, recovery by the reversioner would be more difficult. In the Statute of Gloucester, c. 7 proviled that the reversioner after a tenant in dower might recover during the life of the doweress (where she alienated in fee, in tail, or for life) by a writ of entry in cass prociso, a writ which always recited the Statute. Until 1310 the reversioner still could not recover during the life of a tenant for life or by the curtesy, if the tenant conveyed; in that year there appeared the writ of entry in consimili casn-or, as the Year Book says, "per forman statuti in casu consimili prozisi." On the writs of entry sce Bootn. REas. Actions (1808) 197-99; 3 Holdsworth, History of Enclisir Law (1923) 19; 2 Pollock and Maitland, History of English Lay (1905) 69, n. 2; cf. Jehu Webb's Case, 8 Co. Rep. $45 b, 46 a$ (1609). 
developed through the collaboration of court and chancery officials - if we may believe the story in the Year Book - in the two cases of 1310, Dea'creutr i'. Tuchet ${ }^{45}$ and Stirkcland ${ }^{2}$. Brunolfshead. ${ }^{40}$ In the former, an action brought by an infant remainderman for recovery during the life of the alienor, a tenant for life, the writ granted by the Chancery was abated in the court. The petitioner complained to the Chancery; Bereford. C. J.. was called in to discuss the matter. Bereford said that the writ was not maintainable by the Statute of Gloucester.

"Barncly [Bardelby, Master in Chancery]. The Statute of Gloucester wills that. if women holding in dower alienate, the reversioner shall at once have his recovery; and Westminster the Second wills that in consimili casu, etc.

"Bereford, C. J. Blessed be he who made that Statute. Make the writ and we will maintain it." 47

And no more is heard of this case.

In Stirkcland ''. Brunolfshcad, an action brought by a reversioner to recover inmediately upon an alienation in fee by a tenant by the curtesy, the writ was also abated and again Bereford, C. J., was called in for consultation.

"Four days afterwards the Statute was considered in the presence of BEREFord, C. J. [andi] Bardelby and Osgodby and other examiners of the Clancery, and they amended the writ by this clause: 'in consimili casu provisi' [and then follows the orthodox form of the writ of entry in consinnili casu]." 48

The writ of entry in consimili casu thereafter became a regular writ of course, fixed in form. ${ }^{40}$ It appears from these statements that the writ was a direct derivative of the Statute of Westminster II, chapter 24; but only after strenuous argument was the court willing to consider the various forms of a life estate sufficiently similar to come within the meaning of the Statute.

45. Y. B. Hil. 3 Edw. II. [S. S.] 16 (1310).

46. Y. B. East. 3 Edw. II, [S. S.] 106 (1310).

47. Y. B. Hil. 3 Edw. II, [S. S.] 16, 19 (1310). For this form of the writ of entry in consimili casu see Registrida BREviUm (1687) f. 236.

48. Y. B. East. 3 Edw. II, [S. S.] 106, 109 (1310). In abating the writ Bereford, C. J., had said: "No writ is maintainable outside of the course of the common law [and] 'by the form of the Statute' unless it be expressly given by the Statute. And as to what you say about 'let the clerks of the Chancery agree,' that is to be understood of writs in strange cases; but if your writ had not those words 'by the form of the Statute,' it woukl have some colour and might be maintainable." Id. at 108.

49. Only two years after the introduction of the writ there occurs a case of a writ of entry in consinili casu which is treated by the reporter as any other writ of coursc. Glanville v. Paunton, Y. B. East. 5 Edw. II, [S. S.] 54 (1312). 
Although it is equally clear that the writ of ravishment of ward in socage tenure was formed upon the basis of the in consimili casu clause, it had a somewhat different history. One Agnes Frowyk, early in the reign of Edward II, was procheyne amie to an infant tenant by socage who had been "ravished" and married against the will of both tenant and next friend. Agnes petitioned Parliament for redress, knowing that there was no remedy at law for the injury, ${ }^{50}$ and was told to seek a writ in Chancery formed according to her case. The Clancery accordingly made the slight variation necessary in the established writ of ravishment of ward for knight's service tenure, ${ }^{51}$ and Agnes' case came before the court. The defendants there objected to the form of the writ, but the objections were not sustained by the court. ${ }^{52}$

"Forasmuch as the Statute says 'that a plaintiff leave not the Chancery without remedy,' and this writ has been given by the common counsel of the Chancery according to the plaintiff's case, and is not a writ founded upon the Statute concerning wardship, we adjudge this writ good." 53

Like the writ of entry in consimili casu, this writ of ravishment of ward was originally framed in accordance with the provisions of the Statute of Westminster II, chapter $24,{ }^{\text {,it }}$ and became thereafter a writ of course.

Aside from these two writs, however, there seem to have been no other writs developed specifically upon the basis of the in consimili casu clause, although the Statute was more than once quoted in support of

50. See note 38, supra. The writ of ravishment of ward, a statutory remeds, originated in the Provisions of Merton, 1236, $20 \mathrm{HEN} .3$, c. 6, and was made more useful by the Statute of Westminster II, c. 35; but it applicd only to tenants by knight's service and not to tenants by socage.

51. For the two forms of the writ of ravishment of ward, one for lenants by chivalry and another for tenants by socage, see Recistrus Brevius (1687) f. 161b, 162; FitzHerbert, New Natura Brevium 140.

52. Frowyk v. Leuekenore, Y. B. Hil. 2 \& 3 Edw. II, [S. S.] 157 (1310). Counsel objected to the form of the writ on the ground that it was not warranted by the Statute nor by the common law, but was a new writ. As often happens, the report in the Year Book and the plea roll record differ somewhat. "The report tells of a plea that the boy was of full age, and of issue on that plea. The record shows a justification and a reply $d c$ inturia." Id. at 163 (note by Mfaitland, editor).

53. Id. at 160 . The report continues: "Her action for which her writ is conceived depends [not on the marriage, but] on the ravishment. And the writ is given by the Statute, which says 'let not the complainants [leave the Chancery without remedy']. And it has been fashioned by the common counsel of the clerks of the Chancery. [Wherefore the writ is good enough.]" Id. at 161.

54. Richard Chaunt et ux. v. Anon., Y. B. Mich. 1 Edw. III, f. 19, pl. 3 (1326) is an early example of an action of ravishment of ward in socage tenure Sce also $Y$. B. 9 Hen. VI, f. 61 (1430). 
an unusual writ. ${ }^{55}$ In the case of Tauney $v$. St. Omers, ${ }^{50}$ an action on a writ of right, the plaintiff contended that the provisions in the Statute of Gloucester that the heir should not be barred from his mother's inheritance by his father's deed had been extended by the in consimili casu clause so that an heir would not be barred from his father's inheritance by lis mother's fine. The court rejected this argument and non-suited the plaintiff because he was not within the Statute of Gloucester without making any specific remarks concerning the in consimili casu clause. Three years later the court stated its position concisely. In St. Michael i' Bcanclump, an action upon a writ of entry in casu prosiso, the plaintiff was a remainderman trying to recover immediately after alienation by a tenant in tail. His counsel counted upon the in consimili casu clause as well as upon the Statute of Gloucester rehearsed in the writ, but the court said: "Howard, J. The Statute of Gloucester only says where the reversion, etc., and the Statute of Westminster II clirects that in a similar case there shall be a similar remedy; but these two things, reversions and remainders, are not similar." 58

These cases are strongly suggestive of a conservative attitude on the part of the Chancery and of the courts in their interpretation of the in consimili casu clause of chapter $2+$ of the Statute. The clause could not be relied upon to support an unusual form of a writ unless the plaintiff could show a striking similarity between the case for which the variant form was needed and the one in which the writ of course was usually granted. If the likeness had to be as close as that between the three kinds of tenure for life, if it had to be more apparent than that between remainders and reversions, what reason is there to think that the similarity between an injury done with force and an injury done without force could have been regarded as sufficiently close?

In the early actions of "special" trespass out of which case developed, not only is there no attempt to show a similarity between the facts in the case for which special trespass is brought and those for which an action of "general" trespass would lie. but the emphasis is invariably upon the dissimilarity. Unlike the plaintiffs in the early cases of entry in consimili casu and ravishment of ward in socage tenure, the plaintiff

55. Apparent references to the in consimili casu clause occur in Adam v. Waltham, Y. B. 21 \& 22 Edw. I, [R. S.] 320 (1294) ; Abbot of C. v. Earl of Warren, Y. B. 21 \& 22 Edw. I, [R.S.] 526 (1294); Maltalent v. Romyley, Y. B. Trin. 32 \& 33 Edw. I, [R.S.] 226 (1304). The latter case clearly refers to c. 1 of the Statute. See Rbgistrum BREvivis (1687) f. $199 \mathrm{~b}$ and note 34, supra.

56. Y. B. Trin. $32 \& 33$ Edw. I, [R.S.] 282-290 (1304).

57. Y. B. Hil. $33 \& 35$ Edw. I, [R.S.] 426 (1307).

58. Id. at 430 .

59. For a description of the transitional cases intermediate between the regular action of trespass and the later established action of trespass on the case, see p. 1164, infra. 
in an action of special trespass on the case is interested in showing that the situation is not in consimili casu but is in dissimili casu.

The case of Waldon $v$. Marshall ${ }^{\mathrm{CO}}$ was an action against a horse doctor for negligently killing a horse which he had undertaken to cure.

"Belknap [for the plaintiff]. . . . and this action is brought because you worked your cure so negligently that the horse died, wherefore it is reasonable that we maintain this special writ according to the case, ... . for we can have no other writ.

"Kirton [for the defendant]. You may have a writ of trespass, that he killed your horse, generally.

"Belknap. A general writ we could not have had, because the horse was not killed by force, but died by default of his cure.

"... And then the writ was adjudged good." 01

Clearly outlined by counsel is the distinction between the wrongful killing of a horse by direct force, for which trespass a'i et armis lay, and the wrongful killing of a horse by negligence, for which only the "special" writ was available. Had Belknap hoped to sustain his client's writ upon the authority given by the in consimili casu clause for the framing of new writs, he would no doubt have argued that his case was similar to that for which the regular writ of trespass lay. But instead he attempted to show the great divergence between his client's case and the case for ordinary trespass. There is little reason to think, therefore, that Belknap was aware of any ground for bringing Waldon's special writ within the provisions in the Statute of Westminster II, calling for like cases. ${ }^{62}$

60. Y. B. Mich. 43 Edw. III, f. 33, pl. 38 (1370).

61. Ibid.

62. Two other cases of the period reflect the same attitude of the court. In 1368, a writ of trespass sur le cas was brought against a miller for taking two bushels of grain as multure from the plaintiff, who claimed that he and his ancestors had ground without toll from time out of mind. The court refused to sustain the writ, saying, in the words of Wichingham, J.: "Supposing that he had taken all your grain or half of it, shall you have such a writ because he had taken more than he ought to take for multure? No, you shall not, but a common writ of trespass; and so you shall have here. Wherefore you take nothing by your writ." Y. B. Mlich. 41 Edw. III, f. 24, pl. 17 (1367). Although the court did not state the permissible uses of the writ of trespass stur li cas brought against the miller, they clid say that it would not lie for a taking of grain as multure, for which the common writ of trespass lay. In 1368 the court was thus unwilling to admit that the writ of trespass sur le cas was in that respect a suhstitute for the writ of trespass; for in whatever situation the writ of trespass could serve, trespass sur le cas would not lie. In an action of trespass "on all the matter accorling to the case," against a common innkeeper for lack of care in protecting the plaintifi's goods [Y. B. Pasch. 42 Edw. III, f. 11, pl. 13 (1369)], it is clear that the writ was brought because of negligence, for which general trespass did not lie; it was, therefore, necessary to have the writ "upon all the matter according to the case." General trespass would have served against the innkeeper only had he himself taken the plaintiff's goods. 
The court's riew of the divergence between general trespass and the "special" writ of trespass is seen elsewhere in the Waldon case. The court said that in a writ of trespass the phrases contra paccm and ita negligenter were mutually exclusive. ${ }^{33}$ This opinion is significant of a distinction between forceful injury (contra pacem) and injury from negligence (ita negligenter) so clear cut that it is unlikely that either the Chancery or the court could ever have regarded the injuries as sufficiently similar, within the meaning of chapter 24 of Westminster II, to extend to the latter the remedy for the former.

In the suit brought by Justice Rikhill and others for the disturbance of their easement by the ploughing. of the land of two parsons of Bromaye, Skrene, counsel for the plaintiffs, said:

"This writ is not contra paccm, but is a writ upon our case; and if they had disturbed me with sword or staff or other weapon, I should have made a good declaration against them contra pacom, and I should be well able to maintain it upon my matter."

Skrene was saying that if the disturbance had been with force and arms, he would have brought a general writ of trespass; but the plaintiffs' way across the defendants' land had been disturbed only because the defendants land was ploughed up, and the general writ would not lie. The distinction was between a peaceful disturbance of the plaintiffs' rights and a disturbance which was against the peace, two wrongs which were surcly not within the degree of the sinilarity required by the King's courts for the application of the in consimili casu clause.

The fact that dissimilarity rather than similarity in the actual facts of the case was responsible for the use of the "special" writ of trespass was brought out again in Browne $\approx$. Hazukins. ${ }^{65}$ Townesende, counsel for the defendant, said that one should not combine $v i$ et armis and a recital of special matter in the same writ; the former, a direct injury, was a matter to be remedied by "general" trespass; the latter, a question of negligence. could be remedied only by an action upon the case.

The dissimilarity between the facts leading to a "special" action of trespass and those on which the "general" action could be based is not

63. "Kirton [for the defendant]. Challenge of the writ, in that the writ makes mention contra pacem and in his count he has counted of his cure ita negligenter that the horse died, so that that cannot be said to be against the peace. And the justices were of the opinion that the writ was bad; and then the writ was read and was found not to contain the words contra paccm, wherefore the writ was awarded good." Waldon v. Marshall. Y. B. Mich. 43 Edw. III, f. 33, pl. 38 (1370).

64. Riklinll v. Two Parsons of Bromaye, Y. B. Mich. 2 Hen. IV, f. 11, pl. 48 (1400).

65. Y. I. Trin. 17 Edlw. IV, f. 3, pl. 2 (1477) (action for defamation and threatened assault) ; cf. Y. B. 21 Hen. VI, f. 14, pl. 29 (1+42); Y. B. Mich. 20 Hen. VII, f. 8. pl. 18 (1505) ("And for the nonfeasance of a thing, action upon the case lies . . . for by that I am clamaged, and no general action lies there"). 
only apparent to a modern Year Book reader; but in the Year Book period it was emphasized by counsel and the courts themselves. This would seem to eliminate the possibility that the "special" writ of trespass was formed under the authorization of the clause of the Statute of Westminster II providing that in like cases like remedies were to be granted. From the beginning the necessary difference in the operative factual elements of "special" and "general" trespass would have prevented the application of the in consimili casu clause.

Further doubt is thrown upon the Traditionalist view by an examination of the date at which case began to appear as an established action. A development of the action on the case shortly after the enactment of the Statute of Westminster II would at least make more plausible the theory that the action grew from the Statute than would a development of the action many years later. The opinions of secondary authorities upon the date of the origin of the action reveal a wide discrepancy. Some writers of reputation ascribe the action to the end of the fourteenth century, a hundred years after the statute; others believe it developed at the beginning of that century. ${ }^{66}$ What accounts for this variation of opinion, and which opinion is the more tenable?

Almost without exception modern writers on the origin of the action on the case have taken their examples of the early actions on the case from one or more of these three sources: FitaHerbert's Abridgment, Brooke's Abridgment, or the indices of the Vulgate Year Books. ${ }^{\text {it }}$ Upon the sixteenth and seventeenth century writers represented in these three works, therefore, may be laid some of the responsibility for the varied and often erroneous conceptions of the date of the origin of case. They were probably led astray by a tendency to classify as case all actions in the Year Books of the fourteenth and fifteenth centuries in which case would have been permissible in the sixteenth and seventeenth centuries. That the action of case expanded its scope steadily, and covered many

66. For opinions that case did not develop until the close of the fourteenth century see Garnier, la Notion de Trespass en Droit Angla1s (1927) 27; Mraitlaid, Eguity and tere Forms of Action (1909) 348; PluckNetr, A Concise Histony of the Consaron Law (2d ed. 1936) 335-36; 3 Street, Founnations of Legal Liadiuti (1905) 249. Holdsworth says that actions on the case for conspiracy were common in the time of Edward III. 3 Holdsworte, History of Enclish LAW (1923) 406. Reeves (or Finlason) says that there were a few examples of action sir le case in the Year Bools of Edward I and Edward II. 2 ReEves, History of Ex:GLisu LAw (Finlason ed. 1869) 394, n. a.

67. The cases in 3 Holdsworta, History of Exglisn Lay (1923) 411, n. 1, and in 2 Reeves, History of Exglish Law (1869) 395, are found in the index to the Vulgate edition of the Liber Assisarum. Those in Holsses, The Cosnso: Law (1ES1) 275, n. 2, were apparently taken from Brookz's Abridgessent. Those in 3 Stzezt, FouriDATIONS of LEGAL LIABILITY (1906) 250-252, seem to come from the indes to the VuLGATE YEAR BOOKS. 
more wrongs in the latter period than in the earlier, has never been denied; it is certainly substantiated by the lear Book reports themselves. let modern scholars have been deceived by early writers who classified as case actions which were not called case at the time they were tried.

FitzHerbert's Abridgment and Brooke's Abridgment formed the principle "prinary" source used by lawyers and legal historians until comparatively recent times. FitzHerbert includes some eighteen examples from the fourteenth century reports under the heading Accion sur le Casc. ${ }^{6 s}$ The earliest of these were two cases of the reign of Edward II; one. supposedly from the year 1318 , seems to have been an action on a writ of right, and the other, cited as 1323 , was an action of trespass. ${ }^{60}$ Included also is an action of trespass fron 14 Edward III. ${ }^{\mathbf{7 0}}$ The other fourteenth century actions classified as case came later in the century, 1367 or after. Although all these were placed under the heading Accion sur $l c$ Casc, FitzHerbert said in fact that only seven were examples of actions on the case and eleven were examples of some other form of action. We shall probably never know why he put the latter in the group. Some of the cases were illustrative of actions which case had partially replaced by the sixteenth century; some involved a point of law later important in the development of case; but others had little possible relation to case. Of the eleven citations of actions which were not case, seven were ordinary actions of trespass $\mathbf{7}^{\mathbf{7 1}}$ and four were complaints by bill. usually a bill of trespass - but, at any rate, never a bill of trespass on the case. ${ }^{72}$ FitzHerbert was not even accurate in the seven actions which he called case: Six seem to be citations of actions which were in the transitional process between trespass and trespass on the case; one was a dictum referring to a special judicial writ of trespass, not inrolving an action of trespass on the case at all. ${ }^{73}$

Brooke's Abridgment lists twenty-six items ${ }^{74}$ from the fourteenth century under Accion sur le Case: eighteen of these he said were case.

68. Fitz Herbert, LA Graundf. Adridgemfnt (1565) nos. $31-43,46,47,50-52$. The first edition appeared in 1514.

69. Id. at no. 46 [Y. B. Mich. 11 Edw. II (1318)] ; no. 47 [Y. B. Pasch. 16 Edw. II (1323)].

70. Id. at no. 39 [Y. B. Trin. 14 Edw. III (1339)].

71. Id. at no. 32 [Y. B. Mich. 43 Edw. III, f. 29, pl. 14 (1368)] ; no. 34 [Y. B. Trin. 45 Edw. III, f. 17, pl. 6 (1370)] ; no. 38 [Y. B. Pasch. 31 Edw. III (1356)] ; no. 39 [Y. B. Trin. 14 Edw. III (1339)] ; no. 47 [Y. B. Pasch. 16 Edw. II (1323)] ; no. 51 [Y. B. Trin. 19 Ric. II (1396)] ; no. 50 [Y. B. Pasch. 29 Edw. III, 32 (1354)].

72. Id. at no. 40 [22 Lib. Ass., pl. 41 (1347)] ; no. 41 [30 Lib. Ass., pl. 19 (1355)] ; no. 42 [42 Lib. Ass., pl. 8 (1367)] ; no. 43 [42 Lib. Ass., pl. 9 (1367)]. On procedure by bill see note 99 , infra.

73. Id. at no. 46 [Y. B. Mich. 11 Edw. II (1317)].

74. Brooke, La Gratsde Abridgarent (1576) nos. $14-26,45,48,68,78-83,85,86$, $120,121$. 
In fact only five of the twenty-six seem to be case or transitional actions similar to case. ${ }^{7 \overline{ }}$ The remainder are distributed as follows: trespass, three $;^{\pi 8}$ deceit, two $;^{77}$ conspiracy, two $;^{78}$ bills and miscellaneous actions, nine $;^{79}$ receipt, one $;^{80}$ and four dicta ${ }^{81}$ (which might or might not have really concerned case) made by way of illustration or analogy in the course of the discussion of some other form of action. The earliest example given by Brooke in this group of actions on the case is the action of receipt from 21 Edward III, in the year 1347.

Although both FitzHerbert and Brooke indicated that only a few of the examples classified under the heading of Accion sur le Case were actually case, many of their readers overlooked the fact. That a specific case was reported in one or both of the Abridgments in the chapter on action on the case seemed to later lawyers and scholars to be adequate proof that it was really an example of case, whether or not the Abridgment report or the Year Book report itself warranted the assumption. The later writers were also led astray by the fact that the distinction between a casual dictum and a holding never troubled the sixteenth century lawyer.

The editors of the Vulgate edition of the Year Books share with the compilers of the Abridgments in the responsibility for misleading later readers on the date of the appearance of the action on the case. In marginal notes and in their index classification they labeled reports $A C$ cion sur le Case whenever they thought that case would have lain in their own day, the latter seventeenth century. ${ }^{82}$

The dependence of modern writers upon these three sources for a determination of the date of the origin of case makes the discrepancies in their results understandable. The date accepted depended upon the credulity of the writer. An examination of the opinions of modern

75. Id. at no. 14 [Y. B. 41 Edw. III, f. 24, pl. 17 (1366)] ; no. 15 [Y. B. 42 Edw. III, f. 11 , pl. 13 (1367)]; no. 22 [Y. B. 46 Edw. III, f. 19, pl. 19 (1371)]; no. 24 [Y. B. 48 Edw. III, f. 6, pl. 11 (1373)] ; no. 86 [42 Lib. Ass., pl. 17 (1367)].

76. Id. at no. 19 [Y. B. 44 Edw. III, f. 20 , pl. 16 (1369)]; no. 20 [Y. B. 45 Edw. III, f.17, pl. 6 (1370)]; no. 21 [Y. B. 46 Edw. III, f. 8, pl. 2 (1371)].

77. Id. at no. 17 [Y. B. 43 Edw. III, f. 20, pl. 6 (1368)]; no. 68 [Y. B. 38 Edw. III, f. 13 (1363)].

78. Id. at no. 16 [Y. B. 42 Edw. III, f. 14, pl. 27 (1367)]; no. 23 [Y. B. 47 Edw. III, f. 15, pl. 22 (1372)].

79. Bills: Id. at no. 78 [22 Lib. Ass., pl. 41 (1347)]; no. 79 [26 Lib. Ass., pl. 45 (1351)]; no. 80 [26 Lib. Ass., pl. 62 (1351)]; no. 85 [42 Lib. Ass., pl. 8 (1367)]; no. 120 [38 Lib. Ass., pl. 13 (1363)] ; no. 121 [41 Lib. Ass., pl. 12 (1366)]. Presentments: no. 81 [27 Lib. Ass., pl. 73 (1352)] ; no. 82 [27 Lib. Ass., pl. 74 (1352)]. Nos'cl disseisin: no. 83 [30 Lib. Ass., pl. 5 (1355)].

80. Id. at no. 48 [Y. B. 21 Edw. III, f. 43 (1346)].

81. Id. at no. 18 [Y. B. 44 Edw. III, f. 4 (1369)]; no. 25 [reference not given]; no. 26 [Y. B. 48 Edw. III, f. 25 (1373)]; no. 45 [29 Lib. Ass., pl. 35 (1354)].

82. E.g., Y. B. 44 Edw. III, f. 20, pl. 16 (1369). 
writers and of the cases upon which the opinions rest has yielded interesting results. Of all the cases mentioned or referred to in connection with action on the case, ${ }^{83}$ in no case earlier than the last decade of Edward III, 1367, did the reporter or the participants call it action on the case or trespass on the case at the time it was tried, ${ }^{84}$ and not one from its context seems to bear any definite relationship to the action on the case.

What, then, were the cases earlier than 1367 which are considered by one person or another to have been case? Some of them were ordinary actions of trespass ${ }^{85}$ some were actions for conspiracy ${ }^{80}$ others were actions for deceit ${ }^{87}$ and several were bills of some form or other. ${ }^{88}$ These have most frequently been confused with case. There were a few other miscellaneous actions: debt, ${ }^{80}$ waste, ${ }^{00}$ and some that are hard to iclentify because of the fragmentary nature of the report; one was probably an action of scandalum magnatum, ${ }^{21}$ one seems to have been a writ of ravishment of ward. ${ }^{92}$ one was possibly an action of replevin, ${ }^{03}$ and one was a presentment. ${ }^{9 t}$

The Humber case of 1348 has perhaps been most frequently referred to as a very early. if not the earliest known, example of trespass on the casc. This case presented a complaint by bill against a ferryman on the Humber who had drowned the complainant's mare by overloading his boat. ${ }^{95}$ Careful consideration suggests four reasons why it does not

83. I lave lieen unable to locate one reference, that from X. B. Pasch. $16 \mathrm{Edw}$. II (1323), given by FitzHerbert, but it seems clear from the abstract in the ABRDGMENT that the case was an ordinary action of trespass.

84. The earliest use of the phrase "trespass sur le cas" occurs in the report of a case against a miller. Y. B. Mich. 41 Edw. III, f. 24, pl. 17 (1367). See note 106, infra.

85. Y. B. 29 Edw. III, f. 32 (1354) ; Y. B. Pasch. 31 Edw. III (1356); Y. B. 43 Edw. III. f. 30 (1368) ; Y. B. 44 Edw. III, f. 20 (1369) ; Y. B. 45 Edw. III, f. 17 (1370); Y. B. 46 Edw. III, f. 8 (1371); Y. B. 48 Edw. III, f. 25 (1373); 42 Lib. Ass., pl. 17 (1367).

86. Y. B. 38 Edw. III, f. 13 (1363); Y. B. 42 Edw. III, f. 14 (1367).

87. Y. P. 44 Edw. III, f. 4 (1370) (a dictum concerning deceit).

88. 22 Lib. Ass., pl. 41 (1347) ; 26 Lib. Ass., pl. 62 (1351); 26 Lib. Ass., pl. 48 (1351) : 30 Lib. Ass., pl. 19 (1355); 38 Lib. Ass., pl. 13 (1363) ; 41 Lib. Ass., pl. 12 (1366) ; 42 Lib. Ass.. pl. 8 (1367).

89. 22 Lib. Ass., f. 101. pl. 70 (1347).

90. Y. B. 48 Edw. III, f. 15 , pl. 10 (1373).

91. Y. B. Trin. 14 Edw. III (1339).

92. 29 Lib. Ass.. pl. 35 (1354).

93. Y. B. 21 Edw. III, f. 43 (1346).

94. 27 Lih. Ass., pl. 73 (1352).

95. The Year Book report [22 Lib. Ass.. f. 94, pl. 41 (13.7)] is as follows: "I de $B$ complained hy bill that $G d c F$ on a certain day and year at $B$ on Humber, had undertaken [empris] to carry his mare, worth, etc., on his boat over the Humber river safe and sound; but said $G$ overloaded his boat with other horses as a result of which overloading the mare was drowned, tortiously and to his damage, etc. Richmond. Judgment 
merit classification as an action on the case: ${ }^{80}$ The first is that the plea roll record indicates that the case did not turn on the failure to carry out the agreement to transport the horse safely, but upon the defendant's delict in overloading the boat; issue was joined on the defectum, with no hint of negligence or failure to perform an agreenent, as would have been the issue in an action on the case. ${ }^{97}$ Secondly, the plaintiff's action was neither covenant nor trespass, and therefore was not trespass on the case; for the latter action was considered an integral part of trespass until many generations later. ${ }^{08}$ This is indicated by the statement of Richmond, counsel for the defendant, that "his action should be by way of covenant or by way of trespass." Thirdly, as both the Year Book report and the plea roll record prove, this was an action begun by bill rather than an ordinary common law action begun by an original writ out of the Chancery. ${ }^{99}$ That a wrong was remediable by a bill is no proof that it was remediable by a writ of the same nature; and in this case there was no mention of this as a bill of trespass on the case. Complaint by bill was not an uncommon method of commencing an action in the middle of the fourteenth century, ${ }^{100}$ but it was a method distinct from that of suing an original writ out of Chancery. Finally. neither the report nor the plea roll record said anything about this case

of the bill which does not suppose any tort in us. His action should be by writ by way of covenant or by way of trespass; wherefore, etc., BAskwel., J. It seems that you committed a trespass against him when you overloaded your hont whereby his mare perished. Wherefore answer. Richmond. Not guilty." This case is laleled in the margin Action sur le Case.

96. See Hastings, Note (No. 37, 1935) 13 Butr. Ixst. Hist. Res. 35, conteluding that the common belief that this is the first case of assumpsit is probably erroneous.

97. Id. at 37.

98. The term trespass was applicd, both to the general action of trespass $i d$ at armis and to the "special" action of trespass, until a date much later than the fourtecnth century, so that trespass here would include lsoth the general and the special forms of the action. See Bretherton v. Wood, 3 Br. \& B. 54, 59 (1821), where counsel says that "the reporter has written trespass, meaning probably trespass on the case."

99. Procedure by bill was an alternate methot to procedure by writ in the common law courts. A bill was generally a presentation of the complaint. drawn up by the party himself, rather than a writ issued by the Chancery, and misht he in a language other than Latin. The bill in the Humber case is what is commonly called a bill in the King's Bench, to distinguish it from two hetter known classes of hills. bills in eyre and bills of Middlesex. On the bills in the King's Bench see Bolland, Introduction. in Sezect Bruls in Eyre (Selden Society 1914) xl: Hale, A Discoursi Comcirning the Courts of King's Bchch and Common Plias, in Hanarave LAw Truts (1787) 359, 364-365 (a treatise written long after bills in the hench had ceased to be u-4. I).

100. An examination of the plea roll of the King's Bench on which the Humber ease was found [P. R. O., K. B. 27/354] shows that out of a thousand or so cases on that roll there are about thirty complaints by bill. The bills were all complaints of trespass. mostly of assault, and were all from Berkshire, in which county the King's Pineh was sitting for the term in question, Michaclmas, 22 Edward III. Hastings, supra note 96, at $36,37$. 
being trespass on the case. The only basis for connecting this case with the latter action was the marginal notation in the printed Year Book (made several centuries later).

The Humber case, then, is no exception to the general statement that, as far as we now know, there were no actions like trespass on the case earlier than the last years of the reign of Edward III. Thus for at least eiglity years after the enactment of the Statute of Westminster II the in consimili casu clause had not been used to formulate a writ similar to that of trespass on the case.

Nor is there any indication, when actions of case or transition actions sinilar to case did begin to appear, that the action was considered at that time to be derived from the Statute. Plucknett has made the point that in the lear Book reports of actions upon the case no mention was ever macle of a connection between the action and the Statute. ${ }^{101}$ Both Landon and Holdsworth have tried to argue this away by saying that the omission of any reference to the Statute has no evidential weight because the statutory provision was so well known that a reference would have been unnecessary. ${ }^{102}$ Perhaps they have all overlooked the fact that case was sometimes specifically labeled a common law action.

In an anonymous case of 1505 , an action on the case for diverting water from the stream which fed the plaintiff's mill, Pigot, counsel for the defendant, denanded judgment of the writ because the plaintiff could have brouglht an assize of nuisance. ${ }^{103}$ " . . . for one shall never have an action on the case where he can have other action at the common law." This statement in argument implies that an action on the case was an action "at the common law," and was not connected with any statute.

A more definite statement is found in the judgment of the court in an anonymous case of $1409 .{ }^{104}$ This was a suit brought against a carpenter for the non-performance of a parole promise to build a house; the action has all the earmarks of "special" trespass though it was not specifically called that, and was similar to the action later called trespass on the case.

"HILL, J. Because it seems to the court that this action which is taken at common law is based on a thing which is covenant in itself, of which nothing is shown, the court awards that you take nothing by your writ, etc."

The wide range of subjects covered by the action of case in its fully developed form casts further doubt upon the theory of its derivation

101. Plucknett, supra note 3, 31 CoL. L. Rev. 783.

102. Note (1931) 47 L. Q. Rev. 334, 335; Landon, supra note 5, at 77.

103. Y. B. 21 Hen. VII, f. 30, pl. 5 (1505).

104. Y. B. $11 \mathrm{Hen}$. IV, f. 33, pl. 60 (1409). On this point see also a case the meaning of which is not clear: Say v. Kent, Y. B. Trin. 12 Ric. II [A. F.] 7 (1388). 
from the Statute of Westminster II. Within the boundaries set for it as a remedy for indirect injuries, case expanded in many directions. A number of wrongs for which it early served as a remedy have been noted incidentally: negligent treatment of a horse by a farrier or by a horse doctor; negligent treatment of an injured man by a surgeon; an innkeeper's failure to protect his guest's goods; disturbance of a right of way. From cases for misfeasance and later for nonfeasance in the performance of an agreement, came a large part of the law of simple contract. At a later time, case lay also for waste. And in the role of an action for trover and conversion, a substitute for detinue and for the old criminal actions for theft, trespass on the case produced the law of personal property.

It would be unique to find so large a list of subjects in a statutory action, even in an action evolved by the Chancery under the provisions of chapter 24 of the Statute of Westminster II. Statutory actions and actions such as the writ of ravishment of ward in socage, though developed from a statutory provision, were limited in scope to the specific situation for which the statute provided a remedy. ${ }^{105}$ This same principle generally limited the extension of any new writ formulated by the Chancery. There are many writs in the Register which are said to have been invented by this Chancellor or that clerk, yet most of these writs applied only to one particular circumstance. It seems doubly doubtful, therefore, that the writ of special trespass, or trespass on the case, which not only applied to various situations when it first appeared in the Year Books, but continued to expand without further statutory enlargement, could have come, either directly or indirectly, from the Statute of Westminster II.

To summarize: the Year Book cases furnish strong proof in themselves that the early forms of the action on the case were not derived from the Statute of Westminster II. The fact that counsel and courts stressed the dissimilarity between case and trespass rather than the similarity required under the in consimili casis clause, the fact that the action was regarded as at common law rather than under a statute, the fact that the action on the case covered a wide range of subjects, and finally the fact that the action was not developed until long after the Statute, these items of internal evidence added to the already formidable array of external proof practically destroy the traditional theory that the action of trespass on the case was derived from the in consimili casu clause of chapter 24 of the Statute of Westminster II.

\section{The Development of Trespass on the Case}

That the action of trespass on the case was the result of a common law development independent of the Statute of Westminster II is shown

105. See pp. 1151-54, stpra. 
in the Year Book reports. By a process of evolution and growth the action of case as "special" trespass branched away from the older action of trespass a' ct armis. Thus the action of trespass on the case began its career not as a new and distinct form of action but as a special type of the well known action of trespass - a means developed by the courts to provicle a remedy for injuries caused without direct force which were outsicle of the scope of trespass $v i$ et armis.

In the first case found among the printed judicial records of the fourteenth century in which the phrase trespass sur le cas occurs, a distinction appears to have been made between "common" trespass and the writ in the case. This early action of trespass sur le cas was brought in 1367 against a miller for taking multure when the plaintiff claimed the right to have his grain ground toll-free. ${ }^{106}$ The report indicates a distinction made by both counsel and court between a special writ of trespass sur le cas or sur ma mattcr, and a "general writ with force and arms" or a "common writ of trespass." The use of the words "general" and "common" "writ of trespass. in contrast to the form of the writ of trespass called by the reporter sur le cas, implies that the latter was a special form of the more usual writ of trespass. ${ }^{107}$

A similar distinction occurs in the case of Waldon z'. Marshall. William de Walclon brought a "special writ according to the case" against John Marshall for negligently killing the plaintiff's horse while seeking to doctor it. ${ }^{108}$ Perhaps because the circumstances of the case differed from those in which trespass $\boldsymbol{i}^{\prime} i$ ct armis would lie, ${ }^{100}$ the plaintiff brought a "special writ according to the case." When counsel for the defendant said that the plaintiff might "have a general writ of trespass, that he

106. Y. B. Mich. 41 Edw. III, f. 24, pl. 17 (1367). The form of the writ is given by the reporter: "That when the said John, etc., and his ancestors from time of which memory does not run, were accustomed to grind their grain without multure, etc, the said defendant, etc., with force and arms [ $2 i$ ct armis] interrupted the said complainant from milling without multure" by taking two bushels of grain. The report continues: "Candish [for the defendant] . . a general writ that he took his grain with force and arms lies, and not this writ; judgment of the writ. Belkuap [for the plaintiff]. The writ is taken upon my matter [str ma matter] and if he has taken toll where he ought not to have taken it, I shall have a writ against him. Thorpe. You shall have a quod permittat against the tenant of the soil, and there it shall be tried, and not in a writ against the defendant. . . Wichnsgham, J. Supposing that he had taken all your grain or half of it, shall you have such a writ because he had taken more than he ought to take for multure? No, you shall not, but a common writ of trespass; and so you shall have here. Wherefore you take nothing by your writ."

107. A case of 1369 points to the same conclusion. See note 126, infra. This action was similar to later examples of action on the case against a negligent innkeeper, but it is worthy of note that in 1369 the action was not called "action on the case" or even "trespass on the case."

108. Y. B. Mich. 43 Edw. III, f. 33, pl. 38 (1370).

109. See p. 1156, supra. 
killed your horse," Belknap, for the plaintiff, replied: "A general writ we could not have had, because the horse was not killed by force . . . and then the writ was adjudged good." There is a clear distinction between the writ actually brought and a general writ of trespass. Had Waldon lived two hundred years later his remedy against John Marshall would have been called trespass on the case. Here the writ was regarded by the reporter, and apparently by counsel, not as a new writ with a distinctive name, but as a variation of the established general writ of trespass ai et armis in the form of a "special writ according to the case."

A case of the year 1375 presents a view of the "special" action of trespass which enables us to see how it had already separated to some extent from the parent action of trespass but was still considered part of the parent action. "A writ of trespass upon his case" (sur son cas) was brought against a surgeon for maiming the plaintiff by negligent cure of his wounded hand which the defendant had undertaken (emprist) to heal. ${ }^{110}$ The defendant denied the undertaking, and offered to wage his law as proof. ${ }^{111}$

"Honington [for the plaintiff]. This is an action of trespass and something which falls within the cognizance of the country, in which case wager of law is not allowed, wherefore for default of answer we pray judgment and ask our damages.

"C breach of the peace, so wager of law is acceptable here; . . . and so is the opinion of all the court."

That the defendant's offer of wager of law in this case was sustained by the opinion of all the court indicates that this action of trespass sur son cas was distinguished in their minds from the regular action of trespass. The mode of proof for the latter action was and always had been trial by jury, and wager of law would never have been allowed where there was a breach of the peace.

Yet it would be incorrect to infer from this case that trespass sur son cas was an action entirely separate from trespass. A close relation between them was obviously present in the minds of the counsel and the court. When the defendant offered wager of law, Honington for

110. Y. B. Hil. 48 Edw. III, f. 6, pl. 11 (1375). The first part of the record of the case reads: "And the writ read that when his right hand had been wounded by one $T$. $B$., he against whom the writ is brought undertook [emprist] to cure his hand, but that by the negligence of him J.M. and his cure, his hand was so injured that he was tortiously maimed and to his damage. . . And the writ was not ai ct armis nor contro pacem. Gascoigne. He did not undertake to cure him of his malady as he has supposed; ready to wage his law."

111. In fact the defendant in this case waived his tender of law because he saw an adjournment to the next term. Wager of law was thus not the mode of proof in this case, and it is not a precedent for later actions of trespass on the case. 
the plaintiff declared that this was an unqualified action of trespass. That his client had brought a writ of trespass "upon his case" seemed to Honington no reason for thinking that this was anything other than trespass. Although it sustained the tender of wager of law, the court did not say that the type of action was different from trespass. Nor did they reply to Honington's objections that the action was trespass on the case and not trespass; they merely said that where the writ alleged no breach of the peace. wager of law was permissible. ${ }^{112}$

Cases from the lear Books of the succeeding century show quite clearly that for many years the action which we know as case was in a transitional stage in which it was known as the special form of the general action of trespass. In the action of trespass quare clausum fregit brought by one Thonas Frone in 1409. there was a statement of the situation in which the two types of trespass would lie..13 The question was whether the plaintiff's writ of trespass a $i$ et armis would lie where the property in the sheep concerned was in another: "HANKFord, J. . . For if I lend you certain sheep for a certain time and within the time I take them out of your ward, you will not have a general writ of trespass quare zi et armis, but a writ formed sur le cas, as here."

A similar distinction between the general writ of trespass and the writ "on the case" appears in the case of Hugh G. v. William T. in 1442. ${ }^{114}$ The court, in deciding whether there had been any wrong in William's taking Hugh's child, discussed the following analogy.

"Fulthorpe. J. . . . For in an action of trespass brought against me for a horse wrongfully taken and I say that he himself is seised of the horse (Judgment if the action, etc.) this is a good plea. And so was the rule before Hankford in the King's Bench, and the reason was this: that it would be against reason that he ought to receive

112. Wager of law as a mode of proof in an action of case apparently was never again suggested or accepted. Its appearance in the case of 1375 may indicate that the rules governing the "special" form of the action of trespass were far from fixed. Reeves, to be sure. said that wager of law could be used in actions of trespass on the case, and that for the same reason, i.c.. the lack of $: i$ ct armis in the writ, the plaintiff was entitled to process only hy distraint and not by the capias. 2 ReEves, History of ExGins II LAW (1869) 397. Process by capias in actions of case was provided by the Statute 19 Hex. VII. c. 9 (1503), supposedly to remove this difficulty. It seems that capias was used early in the fifteenth century in actions of "special" trespass. Sce 15 Staffordshirf. Historical Collections (William Salt Archaeological Society 1894) $56,77,86.97,106,107 ; 16$ id. $(1895)$ at 45.49.

113. Y. B. $11 \mathrm{Hen} . \mathrm{IV}$, f. 23 , pl. 40 (1409). In this case Frome charged the defendant with (1) brcaking his close, (2) leading a servant out of the plaintiff's scrvice, and (3) taking some sheep. It turned out in the course of the trial that the sheep had once belonged to the servant. who had lent them to the plaintiff for a year; but sometime, either after or heiore the end of the year, he had taken them again and sold them to the defendant.

114. Y. B. Mich. 21 Hen. II. f. 14. pl. 29 (1442). 
damages for the whole horse, when he himself is seised of the horse, wherefore in such a case he would have a special action of trespass sur son cas supposing that his horse had been long detained. . . .

"PASTON, J. . . . But let us say that my horse was taken with force and afterwards the horse was returned to me [by the taker], I shall have a general action of trespass and not special as has been said."

Although the quotations from each case represent nothing more than dicta, they are significant in indicating that, when the justices wished to differentiate the forms of the action of trespass, they still spoke of one as the "general" action and of the other as the "special" action.

Still later in the fifteenth century this mode of distinguishing the two forms of trespass continued. In the action of trespass sur le cas brought by the Bishop of Salisbury to recover assize and assay of bread and ale in the city of Salisbury, Danvers, C. J., talked at some length about the special writ sur le cas. ${ }^{115}$ The distinction was made again in the action sur son cas brought by Thomas Browne against one Hawkins, for defamation and threatened assault. ${ }^{110}$ Townesende, for the defendant, suggested a hypothetical writ which he said would abate. "for I put matters for two actions in the writ, that is to say, one for action upon the case, the other for a general writ of trespass." In an anonymous case of 1498, an action of trespass on the case for nuisance, this method of differentiation appears. ${ }^{117}$ The plaintiff, a Prior, alleged that the defendant had built a lime pit so close to a certain stream running to his houses in Southwerk that the stream had been polluted, causing the Prior's tenants to leave the houses served by that stream. Keble, for the defendant, challenged the writ because the plaintiff should have "a general writ of trespass quare vi et armis and not a writ upon the case."

It is impossible to read these cases without concluding that to the late fourteenth and fifteenth century legal mind there were two types of trespass, general trespass and special trespass. General trespass was synonymous with trespass $v i$ et armis; and in its early days the form

115. Y. B. Trin. 38 Fen. VI, f. 9, pl. 20 (1459). The Bishop claimed the franchises by virtue of letters patent of Richard II to the Bishop's predecessor. The question before the court was whether the Bishop's writ was good without a statement that the city of Salisbury was a part of the fee of the Bishop's predecessor at the time of the letters patent. In the course of the argument Danvers, C. J., said: "The writ ought to be, quod predictus Episcopus Qucrens in terris et feodis stis predictis, and this which is alleged in the court will make the writ good; but this is not dosse here. This is one of the most important points which should be included in the writ, particularly [nemement] when it is a special writ sur le cas which must include all the matter as clearly as the count."

116. Y. B. Trin. 17 Edw. IV, f. 3, pl. 2 (1477).

117. Y. B. Trin. 13 Hen. VII, f. 26 , pl. 4 (1498). 
of the action of trespass which later became trespass on the case was "special" trespass. When the phrase "on the case" was used in connection with "special" trespass, it was a purely descriptive phrase that referred only to the nature of the writ - a writ "on the case" - and not to the action itself. ${ }^{113}$ "On the case" had had a long history before it became connected with the "special" form of trespass. It occurs in the endorsement to many petitions to Parliament during the period 1300 $1350 .{ }^{119}$ In the petitions the endorsement often read: "Let him go to the Chancery and have a writ upon his case." Although the plirase was applied to many types of writ. the meaning was always, "let him have a writ suitable to the facts of his case," whether the writ was a writ of course, a newly formed writ thereafter to become a writ of course, or a writ of grace, drawn for a peculiar situation. ${ }^{120}$ This general descriptive meaning of the phrase continued after 1350.1:1 In petitions to the King by the Commons during the reign of Henry IV the phrase is used to mean a writ suitable to the plaintiff's needs. ${ }^{122}$ Also, it is

11S. That the "special" form oi the action of trespass was developed to provide a remedy for ccrtain wrongs outside the scope of ordinary writs of trespass at it armis seems a reasonable cunclusion from the cases. Sec pp. $1156 \mathrm{ct}$ scq. supra. If the action had leen statutory, its name would probably have been fixed from the beginning, as in the writ of entry in consimili casu.

119. The early printed Rolls of Parliament contain a number of private petitions to Parliament; some were indersed in this mamer. See note 120, infra.

120. Of the petitions so enclorsed, the first group is composed of petitions for wrongs that could be redressed by regular writs of course, which the petitioner had failed to sue. or that had not availed him because of the offender's influence. Most of the writs reguired were trespass ai ct armis; there were a few examples of conspiracy. Sce, c.g., 1 Rotuli Parliamenturum (1767) 316b, 375a, 321a, 382b, 409a. The petitions in the second group represented situations later remediable by a writ of course which apparently had not developed at the time of the petition. In one case, Frowyk v. Leukenort. the petition was responsible for the establishment of the later writ of course. See 1 Ritcle P.hilamextokim (1767) 278a, 155a; 2 id. at 28a, 39b, 218b. On the use of the in consimili casu clause in Froweyk o. Loukcnore to support the newly formed writ of ravishment of ward in socage tenure, see note 50, supra. The third class of petitions were statements of unusual situations in which extraordinary remedies were required; they were the petitions for writs of grace. See 1 Rotuli ParLiamentorum (1767) 416b, $331 \mathrm{~b}, 439 \mathrm{a} ; 2$ id. at $93 \mathrm{a}, 388 \mathrm{a}$.

121. Of all the petitions endorsed with the phrase "on the case" in the printed Rotuli Parlianisitorum, only two were after 1330; the larger number occurred between 1310 and 1330 .

122. These petitions asked for statutory provisions. One, in 1401, was a petition for the enforcement of the statutes regulating the jurisdiction of the Admiralty [13 RIC. II, (1), c. 5 (1389) ; 15 Ric. II, c. 3 (1391)]. This petition became law in 2 HEN. IV, c. 11 (1400). Another petition, in 1413, was for restriction of the fees charged by the Clurch in testamentary matters, and for some means to compel the ordinary to settle an estate. The provisions were embodied in Statute $4 \mathrm{HEN}$. V, c. 8 (1416). The petitions will be found in 3 Rotuli Parlianentorum (1767) 472b; 4 id. at 9a. 
found applied to forms of action other than trespass, in at least two Year Book reports, one from $1390^{123}$ and the other from 1430.124

It is therefore not surprising to find a descriptive meaning in the phrase "on the case," or its equivalents, in the early actions of "special" trespass. In a case of trespass sur le cas against a miller for taking multure, Belknap, apparently regarding sur le cas as synonymous with "taken upon my matter," said, "the writ is taken upon my matter [sur

123. Abbess of Shaftesbury v. Broncker, Y. B. Hil. 13 Ric II. [A. F.] 108 (1390) (an action of waste). According to the Year Book, the Abbess "porta bref de ziast sur soun caas devers un . . ." Plucknett translates the clause as "brought a writ on the case for waste against one ..." The summary of the case appearing at the top of the Year Book report says, "bref de wast fut porte acers tentant a zolsute et le bref recite soun cas et fut agarde bon quod quere." There can be no doubt that this was an action of waste, rather than an action of trespass on the case. The writ "rehearsed the statute" (presumably the Statute of Gloucester, 1278, 6 EDw. I, c. 5), as was customary in writs of waste; the plea roll record of the case, printed with the Year Book report, is like the record of a regular action of waste. Cf. Monceux v. MLoneeux, Y. B. Hil. 13 Ric. II. [A.F.] 110, 111 (1390). The Abbess sued a writ of waste "on lur case" because Broncher was a tenant at will, who had committed so much damage that the usual means of recovering from a copyhold tenant would have been inadequate. An action of waste lay ordinarily only against freelıolders. It was an extraordinary circumstance, and an extraordinary remedy. See Plucknett in Y. B. 13 Kic. II, [A. F.] silii-sxlv. In the seventeenth century the scope of case was extended to cover waste Icf. Greene v. Cole, 2 Wms. Saund. 252 (1670) ], but that was long aiter the Abbess of Shaftesilury was dead and forgotten. In Plecksett, Coxcisa Histony of Exclusu LaW (2d ed. 1936) 336, the Shaftesbury case is cited to prove that action on the case was known hy that name before the end of the fourteenth century. Dut it seems clear from the Year Book report itself that this interpretation of the case, as an action on the case for waste, instead of an action of waste, is in error.

124. This was an anonymous suit on a writ of deceit "on the case," against a defendant who had sold a butt of bad wine as good wine to the plaintiff. Y. B. Arich. $9 \mathrm{Hen}$. VI, f. 53, pl. 37 (1430). The relationship betwcen the action of trespass on the case and the action of deceit is a complex matter. Deceit, of course. was an old common law action, dating at least from the early thirteenth century [see SErEct CiviL Pleas (Selden Society 1890) pl. 111], but it was an action which at that time lay only for deception of the court. In the early fifteenth century, however, the action seems to have included deception, whether in litigation or in a sale. In the latter field it encountered the new form of trespass, trespass on the case, which could be brought for damage suffered in a fraudulent sale. Apparently for a time the two actions lay for the same wrong; the Registrum BREvitar (1687) has writs of trespass on the case similar to the writ of deceit (upon which the 1430 case was apparently based) given in FitzHerbert's New Natura Brewiuat. See 3 Holuswomth, Histunt of Esiglisu LAw (1923) 386,408 . In trespass on the case for a fraudulent sale the emphasis was upon the damage suffered; in deceit the emphasis was on the deception. Casc fralually drove deceit out of the field of fraudulent sale, and also from the field of iraud in litigation. Cf. Somerton v. Colles, Y. B. Trin. 11 Hen. VI, f. 55, pl. 26 (1432) (action of trespass on the case for deceit) with Y. B. Mfich. 11 Hen. VI, f. 2, pl. 6 (1432) (action of deceit). The action of deceit lingered on as a special remedy for breach of warranty until changes in its nature took place in the eightecuth century. JE:ks, Sront History OF Exglis 
ma matter]." 125 If this was accurate, it is clear that the phrase was not connected with the in consinili casu clause of the Statute of Westminster II. Again in the 1369 case against a common innkeeper, the form of the writ of trespass used coincides with the form of later writs of case against a negligent innkeeper. ${ }^{126}$ Yet the writ used in 1369 was described by the reporter as a writ of trespass "upon all the matter according to the case." This report shows that the later abbreviated form "on the case" in a writ against an innkeeper had the same significance as the fuller plirase used here and that the sixteenth century writ of case against an innkeeper derived its name not from the in consimili casu clause, but from the idea expressed in "upon all the matter according to the case." or from some similar phrase.

Other cases of the late fourteenth century show variation in the form of the phrase, indicative of the fact that the writ of trespass had been altered to fit the case at hand. The writ in the case of Waldon $\boldsymbol{v}$. IIarshall, was called by Belknap "this special writ according to the case." $12 \pi$ In a case of trespass brought against a farrier for laning the plaintiff's horse. ${ }^{1: 88}$ Persay, for the defendant, demanded judgment of the writ because it was a writ of trespass without ai et armis. "Fincuden, C. J. Ife has brought his writ in his case [en son cas], so his writ is good." $1: 9$ The writ in the action against the surgeon was called a "writ of trespass on his case [sur son cas]." ${ }^{130}$ The phrase which later became the official name of the action of "special" trespass, on the case, was

125. See note 106. supra; Y. B. Mich. 41 Edw. III, f. 24, pl. 17 (1367).

126. Y. B. Pasch. 42 Edw. III, f. 11, pl. 13 (1369). See note 107, supra. The report in the Year Book liegins: "Trespass was brought by one $W$ ' against one $T$, an innkeeper and his servant. and he counted how by the common use and custom of England, in the case of the common inn there follows the standard form of the writ; see ReGrsTRtiar BRFicic (1687) f. 104] . . and he counted that he, the said $W$, came on such a day in the town of Canterbury to the said $T$ and there lodged with him, and he had a horse and other goods and chattels, to wit [etc.]; and he took his room and put therein the said goods and chattels and silver, and then he went out into the town for other things; and while he was in the town the said goods and chattels and money were carried from his room by evildoers, through lack of care on the part of the innkeeper and his servants, tortiously and against the peace, to his damage, etc. And he had a writ upon all the matter according to the case."

12\%. Y. B. Mich. 43 Edw. III, f. 33, pl. 38 (1370).

128. Y. B. Trin. 46 Edw. III, f. 19, pl. 19 (1373).

129. This action was described by the reporter simply as "trespass," though it was obviously what later would have been called trespass on the case.

130. Y. B. Hil. 48 Edw. III, f. 6, pl. 11 (1375). In 1372 a writ of trespass "comprising such matter" was brought by a Prior against one John for failure to repair ditches resulting in the inundation of the Prior's land. Y. B. Trin. 45 Edw. III, f. 17, pi. 6 (1372). The writ was abateci because it contained contra pacem where no breach of the peace was alleged. For a later action of trespass on the case for failure to perform customary services, sce Y. B. Trin. 22 Hen. VI, f. 46, pl. 36 (1444) ; cf. RegisTRUM BREYUM (1687) f. 100. 
thus originally descriptive of the writ of trespass clianged to suit the complainant's case.

Nor did the use of phrases interchangeable with "on the case" cease at once. In the case of Rikhill z'. Tavo Parsons of Bromaye, for disturbance of an easement, the report describes the action as one of trespass "containing such matter." 131 Later Skrene said, "This writ is not contra pacem, but is a writ upon our case [sur nostre case]," and Markliam, J., spoke of a "good writ of trespass upon your matter," while Hill said, ". . . it seems reasonable that he should recover by such a writ founded upon his case [foundue sur son case]," 132 Thus in 1400, in a "rit of trespass, the phrase "upon his case" was analogous to "containing such matter," "founded upon his case," and "trespass upon your matter." These phrases were descriptions of the matter contained in the writ and were not in the least words of art.

In the case of Watton $\approx$. Brinth, the plaintiff, counting on the nonperformance of a parole agreement, brought a writ which the reporter called "a writ formed upon special matter." 133 In the action brought against Watkins, millmaker of London, Babington, J., talked of a "good writ of trespass sur le matterc." 134 All these cases show that at the end of the fourteenth century and for some time thereafter, the phrase "on the case" and similar phrases still retained their general descriptive quality. ${ }^{135}$

131. Y. B. Mich. 2 Hen. IV, f. 11, pl. 48 (1400).

132. "Markhan, J. If you have common of pasture in $m y$ land, and I cause all my" land to be ploughed so that your beasts cannot pasture, shall you have a good writ of trespass upon your matter? [As if to say, no.] Hill [serjeant-at-law, in speaking of the plaintiff's writ] ... and for the trespass which has been done to him in the disturbance of his ease, it seems reasonable that he should recover by such a writ founded upon his case"

133. Y. B. Mich. 2 Hen. IV, f. 3, pl. 9 (1400). This is the earliest known example of "special" trespass brought for the non-performance of a parole promise. The writ was not sustained.

134. Y. B. Hil. 3 Hen. VI, f. 36, pl. 33 (1425). The plaintiff brought an action of trespass against Watkins for failure to perform a parole agrcement to malie a mill for the plaintiff by Christmas in a given year. The writ was not sustained. "BAvincron, J. If one makes an agreement [coz'enant] with me to cover my roum or a cortain house within a certain time, and within the time lie does not cover it, so that for deiault of covering the floor of the house all is damaged by the rain, in this case I say that I would have a good writ of trespass sur le mattere shown against him who made the agreement with me." In the next century, the sixtcenth, trespass on the case lay for nonfeasance of a parvie promise; but as eaily as 1435 unc justite was in tavor of the remedy.

135. Other cases from the fifteenth century show how the name of the action on the case was connected with the form of the writ. In an action of trespass sur $l e$ cas in 1429 the plaintiff complained that the defendant had arrested him on two different oceasions when he was going to London ahout judicial business. The plaintiff's count was fuller than the writ; the latter was challenged hy the defendant: "Fullhorpe. The writ is general and the count is special sur lo as, in which ease the writ cunglit to the special. 
But during the fifteenth century "on the case" became definitely attached to the "special" writ of trespass, until finally in the late fifteenth and the sixteenth centuries its association with the "special" form of trespass hecame so strong that its earlier meaning was forgotten. "Action on the case" no longer meant the writ which suited the plaintiff's case, whatever kind of writ that was. but came to be the name of the action which gare a remedy for clamages from an indirect injury of some sort. ${ }^{136}$

Although a fixed name for the action of "special" trespass was slow in developing and the action itself was slow in breaking quite away from the parent action, carly in its histury the form of the writ became different from that for gencral trespass. Long before the action of special trespass became unicersally known as action on the case the form of the writ of special trespass had been distinguished from the form of the writ of seneral trespisss; it omitted the in $^{\prime}$ ct armis and contra pacem phrases of the general writ. and for the conventional description of the uffense in the general writ - quare clansum fregit, de bonis asportatis, or some other - it sulsstituted a more or less careful narration of the iacts of the particular case. ${ }^{33}$

Though the form of the writ of special trespass was differentiated early in its career from that of general trespass, the form of the writ was not fixed from its first appearance. The writ given in the first l'ear Book report of an action of trespass sur le cas, the miller's case of 1368 ,

comprising the substance of the matter. Cottesmorc. In each writ of trespass, one shows more in the count than in the writ. wherefore. etc. Barrsaton. J. The writ is founded sur $1 c$ cas, in which case it ought to have comprised special matter, and this it does not. Wherefore you take nothing by your writ." Y. B. Trin. 7 Hen. VI, f. 45, pl. 24 (1429). Similar statements occur in the report of the Bishop of Salisbury's case [see note 115. supra]. "And judgment of the writ was demanded because this was a writ sur son cas. in which all his matter ought to be expressed, else the writ was worth nothing . . . Danvers. C. J. . . . namely, when it is an especial writ sur lc cas, which must comprise all this matter as clearly as the count." Y. B. Mich. 38 Henl. VI, f. 9, pl. 20 (1459). Townesende speaks of an "action upon my case reciting the special matter," in Browne v. Hawkins. Y. B. Trin. 17 Edw. IV, f. 3, pl. 2 (1477) (defamation and threatened assault).

136. The earliest example in the Year Books of the use of the phrase "action on the case" in a technical manner seems to be the case of John Erich, Y. B. Mich. $34 \mathrm{Hen}$. VI, f. 4, pl. 11 (1455).

137. For a typical writ of general trespass. see Registrum Breviun (1687) f. 93; for a typical writ of case see id. at f. 104. Unfortunately for clarity the writ of case might sometimes contain the phrase at $c^{t}$ armis as a purely descriptive term where the phrase was warranted by the facts of the case. See Y. B. Hil. 39 Hen. VI, f. 44, pl. 7 (1461). FitzHerbert says that the writ of case might even contain the phrase contra pacem, although such a writ must certainly have been very unusual. FrrzHerberr, New Natura Brevica f. 92 E. And in the printed Registrum Brevium (1687), the writs of trespass on the case are not differentiated from the writs of general trespass, but are mixed with the others. 
differed. for instance. from later writs of trespass on the case in that it contained the phrase $z^{\prime} i$ ct armis. ${ }^{138}$

Cases in the succeeding years indicate that there was no general knowledge of the proper form of a special writ of trespass. In IT aldon v. Marshall, the court ruled that contra pacem and ila negligenler were mutually exclusive in a writ of tresipass, so that if incleed the writ of trespass "according to the case" containcel ith nigliginter, it must omit the conventional contra pacim. ${ }^{1.59}$ Likewise in the action of trespass against a farrier in 1.373 the court ruled that the writ of trespass in son cas need not contain the traditional trespass phrase ai al armis. ${ }^{\text {'s" }}$ By 1375. then, it was fairly well settled by court decisions that the " wit of special trespass should not incluke tlice trespass phrases: in the ense against the surgeon of that year. a "writ of trespass upin his case." the reporter thought it well to note in the lear Bonk repurt that "the " was not $z^{\prime} i$ et armis nor contra parcm"."1+1

From the later fourteenth century on, thereiore. the writ of special trespass. or trespass on the case, was well citablished as a viriant iorm of the general writ of trespass. The one iorm of the actim was even contrasted with the other by the difference in the writs. Thus in an anonymous case of 1390 the plaintiff hroughit an action of trespass against a defendant who had borrowed his horse to rikle to a certain place, but had ridden it further on to another and therely. " the horse that the defendant had hacl to kill it. ${ }^{1+2}$ Gascivinne. for the defendant, denanded "judgnient of the writ which says "with force and arms.' for upon his own showing he ought to have had at writ on his case [sur son cas]." Again in the case concerning Iustice Riklill. an action of trespass "upon our case" for disturbance of an easement,

138. Y. B. Mich. 41 Edw. Ill, f. 24. pl. 17 (1368).

139. Y. R. Jich. 43 Edw: III, f. 33, pl. 38 (1370).

140. I. E. Trin. 46 Edw. III, f. 19, pl. 19 (1373) "Persay. He has brought a writ of trespass against us which does not contain the $a i$ ct armis; judgment of the writ. Fincroes. C. J. He has brought his writ in his case. so his writ is gond. Persay. Also he has not supposed in his count that he bailed us the horse to shoe. so it should he understood that if any trespass was done, it was dome against the pence; whereiore judgment. And then the writ was adjudged good."

141. Y. B. Hil. 48 Edw. III, f. 6, pl. 11 (1375) : cl. Y. B. Trin. 45 Edw. III. f. 17, pl. 6 (1371). An action of trespass "comprising such matter" was brought by a Prior for failure to perform customary services; "the urit was contra pacem and for such was challenged and abated for this cause, etc." Later trespass on the case was brought for this case; it is possible that the later form of the writ was dete:mined by the errors in the Prior's case, for the marginal note to the writ in the Register says: "Non dicalur in isto brevi nec constmili contra pacem nostram, fur cen que liel heser fuit abbatus termino Trin. an. 45 E. 3 pur tiel cause." It may be that the writ of case was evolsed by just such a process of trial and error as we see in the Prior's casc. Regrstatar Enetrit' (1687) f. 100.

142. Y. B. 13 Ric. II, [A. F.] 104 (1390). 
Skrene for the plaintiffs said: "This writ is not contra pacem, but is a writ upon our case." 143

The form of the writ of trespass on the case was therefore defined as a writ of trespass that lacked the vi et armis and contra pacem phrases, and included a recital of the special matter. ${ }^{144}$ Yet the cases also show that the form of the writ at one time was not determined by a chancery conference. for in that case the writ would always have been the same. The cases prove that the form was evolved over a period of years, begimning perlaps with the i' it armis form in the miller's case, and was more or less perfected by the time of the surgeon's case of 1375 in which the reporter took such care to note that the writ contained neither $\boldsymbol{z}^{i} i$ et armis nor contra pactm. Had the writ been framed in accordance with the in consimili casu clause, its form would have been settled once and for all time by a chancery conference, just as the writ of entry in consimili casu was established in 1310. The writ of special trespass, however. was a writ of erolutionary growth, a writ in which the writ of general trespass was varied to provide the remedy needed.

The crolution of this special form of the writ of trespass is seen in the lear Book reports of these early cases. There was need at the common law for a remedy for damage suffered for a wrong committed without force. To meet that need, the court permitted the use of a special form of the writ of trespass, a form which omitted the vi et armis and the contra pacem because they were not in accord with the facts of the case. This variation of the general writ of trespass was known first as special trespass or as trespass "upon my matter," but finally became a scparate form of action known as trespass on the case.

The transition was gradual. Beginning as an extraordinary remedy, the special action of trespass continued to be regarded as extraordinary, and was used rather infrequently for a century or so after its first appearance in any form in the Year Books. In the Year Books of the fifteenth and sixteenth centuries up to the death of Henry VII in 1509, seventy-six separate cases are listed in the indices as action on the case. ${ }^{148}$

143. Y. P. Mich. 2 Hen. IV, f. 11, pl. 48 (1400). The case of John Erich, Y. B. Mich. 34 Hen. VI, f. 4, pl. 11 (1455), was an accion sur son cas for a disturbance of the plaintiff's way. "Billing. Again judgment of the writ, for he has supposed a trespass done to his free tenement, which is in the nature of a writ of trespass, and yet he has not said in the writ $\tau^{i}$ ct armis, etc." See Browne v. Hawkins, Y. B. Trin. 17 Edw. IV, f. 3, pl. 2 (1477) ; Y. B. Trin. 13 Hen. VII, f. 26, pl. 4 (1498).

144. See note 115, supra.

145. The space given to accions sur le cas in the Year Book indices increases with each successive reign, but not necessarily because there were morc cases. The Year Book editors began including in the index of the later Year Books two, three, or often more, references to the same case. This has misled modern writers into believing that case had early become "one of the most frequently used of all common-law remedics." 3 Streft, Foundations of Legal Liability (1906) 252. 
At least two others, and probably more, were marked by a marginal note but not listed in the index under case. Of the seventy-six, however, there are only thirty-five which from the Year Book report can be definitely and accurately called examples of trespass on the case. Of the remainder, one case was clearly an action of trespass, and four more were on the borderline between trespass and case. Twenty-nine were dicta concerning the scope or applicability of the special action of trespass which occurred in the report of some different type of action. Of actions for deceit there were three; three more were complaints by bill. of some form or other, and the remaining one was an action which cannot be identified from the brief note in the Year Book.

From these figures it is clear that in the fifteenth century the action of trespass on the case was not the popular action it later became. A detailed study of several plea rolls of the reign of Edward IV (146083 ) indicates that examples of the action of trespass on the case were very rare in the early plea rolls, perhaps proportionately even rarer than in the Year Books. ${ }^{140}$ Thus, the extraordinary cliaracter of the special writ of trespass is shown by the comparative rarity of the ation through much of the Year Book period.

Nor did justices and other legal men cease to regard the action of "special" trespass as unusual for generations after its initiation. In an action sur son cas brought in 1504, the argument turned on whether the plaintiff should have brought debt or detinue instead of his present action. ${ }^{147}$ After declaring that the plaintiff slould have brought an action of debt, Kingsmill, J., said:

"Where a general action lies, there no special action upon the ase lies; as where an assize of nuisance lies, there an action upon the case does not lie; wherefore here, etc. And for the nonfeasance of a thing action upon the case lies, as where an attorney does not execute his office, or a laborer does not do his service in manuring or tilling my land; for by that I am damaged, and no general action lies there."

A century later, in the famous Slade's Case, the extraordinary character of the action was discussed. In this case, an action on the case for assumpsit to recover money owing to the plaintiff from the bargain

146. See Neilson, Introduction, in Y. B. 10 Edw. IV \& 49 Hen. VI. [S. S.] xxixavi. Actions on the case in some form seem to vary from fifteen to forty entries per roll, out of a total of several thousand entries per roll, a very small proportion.

147. Y. B. Mich. 20 Hen. VII, f. 8, pl. 18 (1504). The plaintiff brought his aetion "to wit, that he bought of the defendant twenty quarters of malt to deliver on such a day to the plaintiff, and that the defendant had converted the said quarters to his own use, whereby the action accrued to him." 
and sale of growing grain to the defendant, ${ }^{1+8}$ Doderidge, for the defendant, said: "He should not have an action on the case, which is an extraordinary action and not limited within any certain form in the Register ..." To this the court replied, in giving judgment: "Action on the case on assumpsit is a well formed action and contained in the Register..." And then: "If a man has a manor within any honour and has a leet within his manor of his tenants, if he or his tenants are distrained by the lord of the honour to come to the leet of the honour, he who is so distrained may have a general writ of trespass, or a special writ upon his case ..." and more in the same manner.

This persistent differentiation of the two actions of trespass as special and general may indicate that the special form was not a new statutory creation, but that it was an adaptation of the older and more usual action of trespass $z i$ ct armis to meet a situation to which vi et armis, even in its technical sense, would not apply because of the dissimilarity in the operative facts. It suggests that the special action was the result of a process of gradual evolution out of the old established form of the action of trespass. The assumption of twentieth century writers who have believed that case was a new action created once and for all by the Chancery acting under the powers granted by chapter 24 of the Statute of Westminster II, is unsupported by the opinions of the legal profession during the two centuries or more following the appearance of the special action of trespass. These earlier lawyers never spoke of the action of trespass on the case as a new kind of action, or as a statutory action, but only as an extraordinary form of the common law action of general trespass, adapted to a particular case to which, on account of its facts, the usual form of the writ of trespass could not be made to apply.

148. 4 Co. 92b (1602). That the action of case was a special action was likewise brought out in Isaack v. Clark, 2 Bulst. 309b (1615) (action of case for trover and conversion). 